\title{
Measuring And Changing The Values Of Accounting Students
}

Michael Akers (E-mail: Michael.akers@marquette.edu), Marquette University

Tim V. Eaton (E-mail: tim.eaton@marquette.edu), Marquette University

Don E. Giacomino (E-mail: don.giacomino@marquette.edu), Marquette University

\begin{abstract}
Although prior research has consistently shown that personal values influence behavior, limited research and curricular activity have been conducted with respect to the role of personal values in accounting. This purpose of this paper is to propose a methodology that accounting programs can use to measure the personal values of students. Specifically, we examine the Muser and Orke Typology for measuring personal values. Using students from a comprehensive, private university in the Midwest, we discuss the administration of the instrument and the evaluation of the results. The paper concludes with a detailed description of how accounting programs can apply this methodology to change students' values toward a desired goal.
\end{abstract}

\section{Introduction and Purpose}

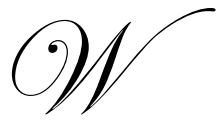

ith the surfacing of major accounting scandals at some of the world's largest companies and the demise of one of the oldest and most respected public accounting firms, the issue of values and ethics in accounting has found itself on the front page of newspapers, as feature articles in magazines and as the subject of best-selling books. International public accounting firms such as Deloitte and Touche are addressing the issue directly. In a 2002 document entitled "Integrity and Quality" they state "The collapse of Enron, like most business failures, is not simply a matter of accounting and auditing. Such failures involve a convergence of factors including personal integrity and ethics ... (2002, Introduction)."

In particular, within the general discussion of ethics is the specific focus on values. For example, Deloitte and Touche lists the core values of the firm as "integrity, objectivity, independence, and technical excellence (Deloitte and Touche, 2002, p.2)." Beyond the values of the firm, they also highlight the importance of the individual values of their employees. "We employ outstanding professionals and instill in all our people the sense that we must always act with integrity and do the right thing. Building on the foundation of people with strong values... (Deloitte and Touche, 2002, p 2, emphasis added)." Perusing statements of other companies and accounting firms will find similar comments. These traits are also highlighted by high-level company officers. A recent survey found that $58 \%$ of CFOs were most impressed with the qualities of honesty and integrity (Messmer, 2003). Unfortunately, as former Andersen Partner Barbara Toffler points out,

Ethics codes on their own have little meaning. Most companies have them, and many of them have been swiped from some other company. A quick survey of corporate values will tell you which ones guide most companies in the United States: honesty, integrity, trust, respect and then maybe commitment, or teamwork. No problem there. But do a little detective work with employee groups and they'll laugh you out of the room. (Toffler, 2003, pp.240-241)

Having ethics codes is not enough. In a recent survey of 100 company ethics officers, only $1 \%$ thought that training alone would have prevented the Enron scandal from happening (Verschoor, 2002). This also has implications for accounting education. Woo (2003) holds that it's not enough to simply make students aware of ethical issues. Her contention is that knowing what is right is not the same as doing what is right. Yet, an impressive body of research crossing many disciplines over the past several decades provides consistent findings 
that personal values do influence behavior (e.g., England 1975, Rokeach 1973, Singhapakdi and Vitell 1993, Guth and Tagiuri 1987, Fritzsche 1995, Finegan 1994, and Eaton and Giacomino 2000, 2001). While the exact definition of personal values differs somewhat among researchers, a representative example is provided by Posner and Schmidt (1987) who define values as "general standards by which we formulate attitudes and beliefs and according to which we behave (p.341, emphasis added)."

An apparent problem is that the individual members of that firm may not necessarily internalize the publicly stated values of many firms. If that were the case, then the behavior of these individuals would be inconsistent with the stated values. Taking it back one more step, the values we may extol as accounting educators may not necessarily be internalized by our students. In the context of accounting education, the faculty needs to determine if the personal values of the students are being changed properly. The purpose of this study is to propose a methodology that accounting programs can use to measure and change students' personal values. The remainder of the paper will proceed as follows. First, we introduce the Musser and Orke Typology for measuring the personal values of students. Next, we discuss specific procedures for administering the values instrument and interpreting the results. We provide an example of this using students from a comprehensive, private university in the Midwest. Results are analyzed and discussed on several levels. We conclude with a step-by-step discussion of how accounting programs can apply this methodology to change students' personal values toward a desired end.

\section{The Musser And Orke Typology Of Values}

We believe that a typology of values developed by Musser and Orke (1992) can be useful as an intervention procedure for improving students' personal values. The typology of values is based on results from the Rokeach Value Survey. The Rokeach (1973) instrument contains rank-ordered human values; "instrumental values" guide behavior toward the end-states or "terminal values". Musser and Orke classify the terminal values into "social" and "personal" categories, and the instrumental values into "moral" and "competence" categories. The values for each of the categories in the Musser and Orke Typology are provided below. We have added a hypothetical set of rankings that will be used in the scoring example.

Respondents rank each of the 18 values in each set in terms of their importance from 1 (highest) to 18 (lowest). The Musser and Orke methodology then uses these rankings to develop a 2 x 2 value system typology matrix to classify the four basic values systems types, which are shown in Figure 1. According to the typology, Effective Crusaders (upper left quadrant) score high on competence instrumental values and social terminal values. Virtuous Advocates (upper right quadrant) score high on moral instrumental values and social terminal values. Independent Maximizers (lower left quadrant) score high on competence instrumental values and personal terminal values. Honorable Egoists (lower right quadrant) score high on moral instrumental values and personal terminal values.

\begin{tabular}{|c|c|c|c|}
\hline \multicolumn{4}{|c|}{ TERMINAL VALUES (end states) } \\
\hline SOCIAL (focus on others) & Rank & PERSONAL (self-centered) & Rank \\
\hline A World at Peace & 13 & A Comfortable Life & 17 \\
\hline A World of Beauty & 11 & An Exciting Life & 18 \\
\hline Equality & 4 & A Sense of Accomplishment & 9 \\
\hline Family Security & 2 & Health & 3 \\
\hline Freedom & 6 & Inner Harmony & 10 \\
\hline Mature Love & 12 & Pleasure & 15 \\
\hline National Security & 5 & Salvation & 1 \\
\hline Social Recognition & 16 & Self-respect & 14 \\
\hline True Friendship & 8 & Wisdom & 7 \\
\hline $\begin{array}{l}\text { Total } \\
\text { Score (171-77) }\end{array}$ & $\begin{array}{l}77 \\
\mathbf{9 4} \\
\end{array}$ & $\begin{array}{l}\text { Total } \\
\text { Score (171-94) }\end{array}$ & $\begin{array}{l}94 \\
77 \\
\end{array}$ \\
\hline
\end{tabular}




\begin{tabular}{|c|c|c|c|}
\hline \multicolumn{4}{|c|}{ INSTRUMENTAL VALUES (means) } \\
\hline MORAL (focus on moral means) & Rank & COMPETENCE & Rank \\
\hline Broadminded & 9 & Ambitious & 16 \\
\hline Forgiving & 15 & Capable & 7 \\
\hline Helpful & 5 & Clean & 10 \\
\hline Honest & 1 & Courageous & 8 \\
\hline Loving & 2 & Imaginative & 18 \\
\hline Loyal & 4 & Independent & 14 \\
\hline Obedient & 17 & Intellectual & 13 \\
\hline Polite & 3 & Logical & 11 \\
\hline Responsible & 6 & Self-controlled & 12 \\
\hline $\begin{array}{l}\text { Total } \\
\text { Score (171-62) }\end{array}$ & $\begin{array}{l}62 \\
109 \\
\end{array}$ & $\begin{array}{l}\text { Total } \\
\text { Score }\end{array}$ & $\begin{array}{l}109 \\
62 \\
\end{array}$ \\
\hline
\end{tabular}

Musser and Orke indicate that people possessing the different value types behave quite differently. In a validation study, Musser and Orke developed matches between famous people and specific value types. They identified Mother Teresa and Mahatma Gandhi as Virtuous Advocates, Oliver North as an Effective Crusader, Donald Trump and Ivan Boesky as Independent Maximizers and Arsenio Hall as an Honorable Egoist. According to Musser and Orke, these are the behaviors associated with each value type.

- $\quad$ Virtuous Advocates are primarily concerned with helping the organization reach its goals rather than obtaining their own personal goals. They also tend to go about helping the organization achieve its goals in a manner that is sensitive to the needs and feelings of their associates. This other-centered, other-sensitive focus creates trust and helps associates risk more and be more innovative.

- Independent Maximizers are more concerned with seeking personal goals rather than those of the organization. They also strive to obtain these personal goals in an impersonal manner that often ignores the needs and feelings of their associates, which may lead to mistrust with team members. As a result, associates are less willing to take risks and eventually become stagnant.

- $\quad$ Honorable Egoists seek to achieve personal goals over those of the organization but attempt to do so in a manner that is sensitive to the feelings of their associates. However, team members may view these people with suspicion because of their primary focus on individual goals. Therefore, they are less likely to take risks and be more innovative.

- $\quad$ Effective Crusaders primarily seek to achieve organizational goals but they often go about doing this in a way that is insensitive to their associates. Therefore, team members often find themselves in a love-hate relationship with these leaders. They want to love them because they are trying to help the team meet its goals but their methods produce hurt and alienation.

\section{Scoring Procedure}

Musser and Orke established a scoring procedure to identify value system types. In three college studies they validated the cutoff values used for identifying the value system types. This is the procedure:

\section{Step 1: Compute the score for each set of values.}

- Social Terminal Values consist of Equality, Family Security, Freedom, Mature Love, National Security, Social Recognition, True Friendship, A World at Peace and A World of Beauty. The score for these values is determined by subtracting the total rankings of these nine values from 171 (the sum of rankings for all values in the set). This method is equivalent to assigning the highest rated value a score of 18 and the lowest rated value a score of 1 . In our example, the sum of the rankings for the social terminal values is 77 , and the score for the social terminal set of values would be 94 (which is 171-77). 
- $\quad$ Personal Terminal Values consist of the remaining terminal values. The score for these values is 77 (17194). Thus, these scores would place the respondent in the upper portion (Matrix (depicted in Figure 1), since the score 94 for the social terminal category is above the cutoff of 78.5.

- Moral Instrumental Values consist of Broadminded, Forgiving, Helpful, Honest, Loving, Loyal, Obedient, Polite and Responsible. The same procedure is followed as for (a) above to determine the score for instrumental values.

- $\quad$ Competence Instrumental Values: The sum of rankings for those values is then subtracted from 171 to get the competence instrumental score. In our example, the respondent's rankings for these values total 62 , then the moral instrumental score is 109 (which is 171-62). This score would put the respondent in the right portion (high moral) of the Value System Matrix, because the score is above the cutoff of 93.5.

\section{Step 2: Classify the respondents according to value type.}

Using the example above, the respondent's scores of 94 for social terminal and 109 for moral instrumental place him/her in the upper right quadrant of the Value System Matrix (Figure 1). Thus, the respondent is classified as a Virtuous Advocate.

Figure 1: Value System Matrix

(Respondent's Scores are 94 for Social Terminal and 109 for Instrumental Values)

\begin{tabular}{|c|c|c|c|c|}
\hline \multirow{4}{*}{$\underline{\text { Terminal Values }}$} & & \multirow[b]{3}{*}{78.5} & $\begin{array}{l}\text { High Competence } \\
\text { (CI) }\end{array}$ & $\begin{array}{l}\text { High Moral } \\
\text { (MI) }\end{array}$ \\
\hline & $\begin{array}{l}\text { High Social } \\
\text { (ST) }\end{array}$ & & $\begin{array}{l}\text { Effective Crusader (EC) } \\
\text { - Concern for others } \\
\text { - Competence for social goals } \\
\text { - Associated with Oliver North } \\
\qquad \text { ST }>78.5 \text { and CI }>93.5\end{array}$ & $\begin{array}{l}\text { Virtuous Advocate (VA) } \\
\text { - Concern for others } \\
\text { - Moral means for social goals } \\
\text { - Associated with Mother Teresa } \\
\text { and Mahatma Gandhi } \\
\text { ST > 78.5 and MI > 93.5 } \\
\text { RESPONDENT }(\mathbf{9 4 , 1 0 9 )}\end{array}$ \\
\hline & \multirow[t]{2}{*}{$\begin{array}{c}\text { High Personal } \\
\text { (PT) }\end{array}$} & & $\begin{array}{l}\text { Independent Maximizer (IM) } \\
\text { - Concern for self } \\
\text { - Competence for personal goals } \\
\text { - Associated with Trump, Boesky } \\
\qquad \text { ST }<78.5 \text { and CI }>93.5\end{array}$ & $\begin{array}{l}\text { Honorable Egoist }(\text { HE) } \\
\text { - Concern for self } \\
\text { - Moral means for personal goals } \\
\text { - Associated with Arsenio Hall } \\
\qquad \text { ST }<78.5 \text { and CI }<93.5\end{array}$ \\
\hline & & \multicolumn{3}{|c|}{93.5} \\
\hline
\end{tabular}

\section{Changing Students' Values}

This section discusses how to use the results of the Musser and Orke instrument to identify and change students' values toward a desired goal. This discussion includes the following steps:

\section{Step 1: Determine the desired value type}

There are two important aspects regarding the determination of the desired value types (goal). First, the accounting department faculty, utilizing input from outside sources such as an advisory board and/or from the alumni, needs to determine and agree on the desired goal. Our advisory board and alumni provided us with valuable input as we developed our assessment program. Second, the desired goals have to be consistent with values 
espoused by the department, institution and professional accounting organizations. For example, the University's mission includes "the fostering of personal and professional excellence, the promotion of a life of faith, and the development of leadership expressed in service to others." Our accounting department mission statement states that we "prepare students to be responsible, competent and ethical leaders ... we emphasize leadership and service through the internship program and Beta Alpha Psi." Prior research (Akers and Giacomino, 1999, 2000) that compared professional accountants' values with values embodied in codes of conduct of professional organizations (i.e., AICPA, IIA) and values listed in the literature of specific firms identified a variety of values including: honesty, obedience, competence, independence, loyalty, ambition, objectivity, responsibility, success, intelligence, innovation, and personal involvement in relationships.

The desired goals are established by considering both the university's values and department's values along with professional values. Because our university places a large emphasis on service to others, examples of the desired goals are as follows:

- Virtuous Advocates-minimum of $60 \%$ of accounting students

- $\quad$ Effective Crusaders-maximum of $15 \%$

- Independent Maximizers-maximum of $10 \%$

- Honorable Egoist-maximum of $15 \%$.

Such goals are consistent with the values of our university and values of professional organizations and accounting firms.

\section{Step 2: Use the Musser and Orke methodology to classify students by value type}

We administered the Rokeach Values Survey to 163 students in four different classes; principles, intermediate, advanced and auditing. Of that group, 84 of the students are accounting majors. Figure 2 is a summary of the percentages for each value type for those accounting majors. The data can be broken down further by gender, class and major. The results of our survey show that students are evenly split with respect to focus on moral vs. competence means and almost evenly split with respect to focusing on others (47.6\%) vs. self (52.4\%). Independent Maximizer (31\%) is the most frequent value type, followed closely by Virtuous Advocate (28.6\%).

Figure 2: Value System Matrix Summary - Accounting Majors Actual vs. Goal For System Types

\begin{tabular}{|c|c|c|c|c|c|}
\hline \multirow{8}{*}{$\underline{\text { Terminal Values }}$} & \multirow{5}{*}{ High Social } & \multicolumn{4}{|c|}{ Instrumental Values } \\
\hline & & \multicolumn{2}{|c|}{ High Competence } & \multicolumn{2}{|c|}{ High Moral } \\
\hline & & \multicolumn{2}{|c|}{$\begin{array}{l}\text { Effective Crusader (EC) } \\
\text { (Oliver North) }\end{array}$} & \multicolumn{2}{|c|}{$\begin{array}{r}\text { Virtuous Advocate (VA) } \\
\text { (Gandhi, Mother Teresa) }\end{array}$} \\
\hline & & Actual & $19 \%$ & Actual & $28.6 \%$ \\
\hline & & Goal & $15 \%$ & Goal & $60 \%$ \\
\hline & \multirow{3}{*}{ High Personal } & \multicolumn{2}{|c|}{$\begin{array}{l}\text { Independent Maximizer (IM) } \\
\text { (Boesky, Trump) }\end{array}$} & \multicolumn{2}{|c|}{$\begin{array}{l}\text { Honorable Egoist (HE) } \\
\text { (Arsenio Hall) }\end{array}$} \\
\hline & & Actual & $31 \%$ & Actual & $21.4 \%$ \\
\hline & & Goal & $10 \%$ & Goal & $15 \%$ \\
\hline
\end{tabular}




\section{Step 3. Decide on desired direction of changes in value type}

Our institution's focus on the importance of service to others and using moral means suggests that we set high goals in terms of the percentage of students who emphasize serving others through the use of moral means. In other words, we would like to increase the number and percentage of accounting students who are Virtuous Advocates. Figure 2 also includes some hypothetical goals for each of the value types, with the Virtuous Advocate percentage set at a minimum of $60 \%$, Honorable Egoist and Effective Crusader at $15 \%$ each (maximum), and Independent Maximizer at $10 \%$ (maximum). Next, we discuss the methods that we use, or that other programs might use, to change the values of the students and to change the value types profile in the value system matrix depicted in Figure 2.

\section{Step 4: Develop methods for moving the students' values types toward the goals}

We suggest three categories of activities that can be used to move the students' values toward the suggested goals: 1) Programmatic activities. Those are activities internal and external to the university and the accounting program that focus on using moral means for attaining social goals. 2) Curriculum activities are current and potential courses that examine individual values that impact behavior. 3) Classroom activities are assignments that demonstrate and reinforce the importance of values within the accounting profession. For each category we provide a list of suggested activities and some brief comments as to how we are using these activities.

\section{Programmatic Activities}

- $\quad$ Student involvement in service activities through student groups such as Beta Alpha Psi (BAP) and accounting clubs. Our BAP chapter has been very active in performing a variety of service activities such as visiting nursing homes, administrative assistance with the MS walk and special Olympics, tutoring beginning accounting students.

- $\quad$ Student involvement in civic activities such as soup kitchens, Red Cross, Children's Hospital, AIDS Walk/Run and Hunger Cleanup. Our campus ministry program encourages students to become involved in such civic activities and has developed a list of these opportunities.

- Income tax assistance for the elderly and the poor. While our BAP chapter has provided this assistance for many years to individuals in the nearby neighborhood, this opportunity is available to all of our accounting majors.

- $\quad$ Fundraisers for scholarships. Our BAP chapter, along with other accounting majors, has been involved in two activities for many years where funds have been raised that are used for scholarships, an auction and internal control work for a large festival held each summer in Milwaukee.

- Joint service projects where students interact with professional accountants and faculty. To date our students have not been involved in service activities with professional accountants and there have been only limited activities, such as Hunger Cleanup, where faculty and students have worked together.

Using our suggested goals (primarily virtuous advocates), we suggest a debriefing session after such service projects to discuss the reasons/motivations for performing the service. If the students perform the service primarily to list on the resume or to obtain superior status for BAP, this is inconsistent with our suggested goals.

\section{Curriculum Activities}

- $\quad$ Offer a course on service learning. We offer a course on service learning in the College of Business that can be taken as an elective by all business majors. The students work with a nonprofit organization and provide assistance related to their major.

- $\quad$ Require an ethics courses as part of the program requirements. Similar to technology and communications skills students need to be exposed to ethical situations and examine the values that will affect how they will behave. We require our students to take two ethics courses (Theory of Ethics and Business Ethics) that are taught in the College of Art and Sciences. 
- Offer a separate business ethics course. If an ethics course is not offered or if such a course doesn't address ethical situations in business, a separate business course should be considered.

- Integrate ethics into all accounting courses as deemed appropriate. Similar to communications and technology skills, ethical situations should be incorporated to all accounting courses.

- Consider offering a course on fraud detection, white-collar crime or forensic accounting. Since our criminology department has only occasionally offered a course on white-collar crime, we are considering a course on fraud detection. Such a course will examine values that impact both ethical and unethical behavior.

The curriculum activities that we have suggested will emphasize the importance of ethical behavior and the values that are important to us. Since most states have adopted the 150-hour requirement, accounting programs should take advantage of this opportunity to include an ethics, fraud/white collar or service-learning course into the curriculum.

\section{Classroom Activities}

- Use examples/cases of service orientation within the accounting profession. For example, an auditing course could utilize a case where students evaluate internal controls of a civic organization. While the study of internal controls is important, emphasis should be directed to the service aspect of the project.

- Use cases and exercises that emphasize means versus the ends. For example, a discussion as to why an accountant might serve on the Board of a non-profit organization could be utilized. Is the purpose to obtain a client, add credentials to a resume or to provide a service?

- Educate students on the importance of service within a profession. This can be done in all accounting courses.

- $\quad$ Keep the course up-to-date by including timely articles that are relevant on ethics and values that are relevant to the particular course. Our faculty currently uses such items in their respective courses.

- $\quad$ Use more cooperative learning assignments.

- $\quad$ Cover topics such as earnings management where values can impact the behavior of the accountant. We discuss this particular topic in our financial statement analysis course as well as our Intermediate and Advanced courses.

- $\quad$ Show relevance of personal values to ethical standards. An example is a discussion of the values embodied in the AICPA ethical standards as the topic is addressed in an auditing course.

The classroom activities that we are suggesting, similar to the curriculum activities, illustrate the relevance and importance of values and how such values affect behavior.

\section{Summary and Conclusion}

Very little research and curricular activity have been done with respect to the role of personal values in accounting. The primary purpose of this manuscript has been to illustrate a methodology that can be used both to measure and change the personal values of accounting students. We believe that many benefits can be obtained from using the expertise of those in other fields. In this paper we demonstrated how accounting educators could use the Musser and Orke Typology of Values. We also provided an illustrative step-by-step example of how this methodology can be utilized. While we have included several specific illustrations from our university as an example, we believe that all institutions can find the methodology helpful and adaptive towards their respective goals. Our hope is it will be one type of effective tool that can be used as we as accounting educators strive to positively influence the next generation of accountants. 


\section{References}

1. Akers, M.D. and D.E. Giacomino. 2000. "Ethics and The Accountant's Code of Conduct", The Journal of Applied Business Research. Vol. 7:87-95.

2. Akers, M.D. and D.E. Giacomino. 1999. "Personal Values of Certified Internal Auditors", Internal Auditing. (January/February): 19-27.

3. Deloitte and Touche. 2002. Integrity \& Quality. New York, Deloitte \& Touche LLP.

4. Eaton, T.V. and D.E. Giacomino. 2000. "Personal Values of Business Students: Differences by Gender and Discipline", Research on Accounting Ethics. V. 7:83-102.

5. Eaton, T.V. and D.E. Giacomino. 2001. "An Examination of Personal Values: Differences Between Accounting Students and Managers and Differences Between Genders", Teaching Business Ethics. V. 5:213-229.

6. England, G.W. 1975. The Manager and His Values: An International Perspective from the United States, Japan, Korea, India, and Australia. Cambridge, MA: 5-67.

7. Finegan, J. 1994. "The Impact of Personal Values on Judgments of Ethical Behavior in the Workplace", Journal of Business Ethics 13: 747-755.

8. Fritzsche, D.J. 1995. "Personal Values: Potential Keys to Ethical Decision Making", Journal of Business Ethics (November): 909-923.

9. Guth, W. and R. Tagiuri. 1965. "Personal Values and Corporate Strategies", Harvard Business Review 43: 123-132.

10. Messmer, M. 2003. "Does Your Company Have a Code of Ethics?", Strategic Finance. (April): 13.

11. Musser, S. J. and E. Orke. 1992. "Ethical Value Systems: A Typology", The Journal of Applied Behavioral Science. 28(3): 348-362.

12. Posner, B., and W. Schmidt. 1987. "Managerial Values Across Functions: A Source of Organizational Problems", Group and Organization Studies 12(4): 373-385.

13. Rokeach, M. 1973. The Nature of Human Values. New York, Free Press.

14. Singhapakdi, A. and S. J. Vitell 1993. "Personal and Professional Values Underlying the Ethical Judgments of Marketers", Journal of Business Ethics. Netherlands 12: 525-533.

15. Toffler, B. 2003. Final Accounting: Ambition, Greed and the Fall of Arthur Andersen. New York, Broadway Books.

16. Verschoor, C. 2002. "It Isn't Enough to Just Have a Code of Ethics", Strategic Finance. (December): 22-24.

17. Woo, C. J. 2003. "Personally Responsible". BizEd. (May/June): 22-27. 